\title{
A study on Latest Management Governance Techniques in Indian Companies
}

\author{
${ }^{1}$ Alexander C. V. J Victoria, ${ }^{2}$ Dr. M. Ganesan \\ ${ }^{I}$ Research Scholar, Department of Management Studies, Bharath University \\ ${ }^{2}$ Professor, Research Guide, Department of Management Studies, Bharath University
}

\begin{abstract}
Management cum governance is considered as a proactive controlling mechanism for protecting best interests of all the stakeholders of any companies. Despite a lot of initiatives has been taken around the world in the form of codes / laws for ensuring good governance for corporate sector, the issue of mutual fund governance had not been discussed in detail. But, in view of the growth of that industry and the magnitude of public funds the mutual fund companies are managing over the years, a renewed interest on its governance mechanism is the need of the hour. Here, in this paper, an attempt has been made to enquire the governance practices of Indian mutual fund industries. After studying the governance structure of asset management companies (AMCs) of the sample mutual fund companies, it was found that the structure and composition of board of directors of these AMCs were not encouraging enough with a little and sometimes no information about the functioning of the board of these AMCs. Under this circumstance, measures for improvement of governance and disclosure standards are expected from regulatory body like SEBI.
\end{abstract}

Keywords: Corporate Governance; Mutual Fund Companies; Asset Management Companies; Board of Directors.

\section{Introduction:}

The term 'governance' is not only regarded as a buzzword in management literature, but also is considered as the much-debated issue that may directly or indirectly influence every walk of public life . Every stakeholder in all types and kinds of enterprise expects good governance prevailing in the concern. However, the word 'governance' has a Latin route 'gubernare', which denotes 'to steer'. Corporate Governance may therefore be interpreted as related to the guidance of a company's affairs. Although the subject has been mooted since 1600 with a Royal Charter being granted to the East Indian Company, which was to be governed by a Court of Directors, it has certainly experienced a significant increase in interest over past decades, with several countries issuing new governance reports or codes, and several countries issuing codes of best practices. The term 'Corporate Governance' conveys about how a corporation is directed and controlled under a set of mission, values, and philosophy. It is a phrase implying greater transparency of management system in corporate entities. In common parlance, it is a relationship among various participants in determining the direction and performance of a corporation. However, in its broadest sense, Corporate Governance is all about the stewardship responsibility of corporate directors to provide oversight for the goals and strategies of a company and to foster their timely implementation, thereby, facilitating the accomplishment of the ultimate mission. But, unfortunately over the time, the common investors all over the globe had been suffered a lot in the hands of the greedy managers and the scams like Enron, Adelphia, Tyco, Worldcom, Xerox, Paramalt, Satyam had shattered the trust of the common investors in the very mechanism of corporate management and governance. The governance mechanism of financial service sectors like banks and mutual fund industries are also under severe criticism and scrutiny at the aftermath of great financial crisis in the mid part of first decade of twenty-first century that shattered a number of economies, played a major role behind bankruptcy of numerous companies, created a huge unemployment etc. In order to restore their trust in the system, regulatory bodies all over the world had taken a lot of measures for ensuring that the good governance should prevail not in mere words but in true spirits. Here, in this paper an attempt has been undertaken to study the state of affairs of governance structure of mutual fund companies operating in India. The mutual fund sectors in India, since after the LPG efforts in early part of last decades in twentieth century, is a growing industry in terms of accelerating client base, both from corporate and individual sectors. As on $31^{\text {st }}$ March, 2010, there were 4.77 crores investor accounts with various mutual funds, out of which 4.73 crores belonged to resident individuals and NRI investors. Moreover, the assets under management of these mutual funds exceeded rupees seven lakh crores by 2010. Since, a huge amount of public money is in the hands of these professional portfolio managers, hence it is worthwhile to enquire the management structure of these mutual fund industries in line with the provisions of good corporate governance around the world. 


\section{Objectives of Study:}

In this modern world of liberalization and globalization, the world is transforming into a global village and when the concepts of national frontiers and trade barriers are becoming obsolete and terms like FDI, FPI, GDR and ADR got ready references in general discussion at every nook and corner, the companies are seriously thinking about fighting against the foreign competition within the country and at the same time going overseas either through direct route or merger and acquisition route. Therefore, they have to put importance on the way their corporations are governed in this fiercely competitive arena. This observation is supported by a recent survey conducted by internationally acclaimed management consultancy house, McKinsey \& Co. (2000) which reveals that more than $2 / 3^{\text {rds }}$ of Foreign Institutional Investors (FIIs) are putting Corporate Governance high on their agenda at the time of investing their money in any concern. Therefore, for survival and growth, adherence to Corporate Governance mechanism is a pre-requisite. Although the corporate governance mechanism, in common parlance, is generally being associated with joint stock companies, yet a growing awareness of implementing a good governance mechanism in financial services sector in general and banking and mutual fund industries in particular may be observed.

Governance scandals in publicly listed banks undermine public confidence in the public equity markets and banking sector, hence poorly governed banks and financial institutions threaten the stability of the banking system or whole financial system. The corporate governance of banks in developing economies is important for several reasons. First, banks have an overwhelmingly dominant position in developing economy financial systems, and are extremely important engines of economic growth [King and Levine 1993; Levine 1997]. Second, as financial markets are usually underdeveloped, banks in developing economies are typically the most important source of finance for the majority of firms. Third, as well as providing a generally accepted means of payment, banks in developing countries are usually the main depository for the economy's savings. Fourth, many developing economies have recently liberalized their banking systems through privatization/disinvestments and reducing the role of economic regulation. In India, although the issues of corporate governance have not received much attention in the first generation of financial sector reforms, this issue will become a natural choice in the second set of reforms. In case of mutual funds, shareholders are also clients of funds. Due to this special organizational structure, conventional results in corporate governance studies may not apply in the fund industry. Fama and Jensen (1983) argue that boards of mutual financial institutions are less important in the management control process compared to those of non-financial corporations. Shareholders' ability to withdraw resources directly from funds serves as a form of liquidation. So, the market discipline carried out by investors is measured by flow sensitivity to past performance. Investors punish (reward) fund management by withdrawing money from (adding to) the fund following deterioration (improvement) in performance. Such punishment and rewarding behavior generates a positive relation between fund returns and subsequent net flows namely flow sensitivity. When the flow sensitivity is high, increasing return becomes an appealing method to increase fund size. High returns benefit investors and expanding fund size is in the interest of management, because the management fee is calculated as a percentage of the total assets overseen. Therefore, high flow sensitivity can align the interest of the management and investors. The fiduciary failure in the scandal is captured in three measures-firstly, whether the fund is indicted by the SEC or any other regulators for facilitating arbitrage trading; secondly, whether management prevents arbitrage ex-anti by adopting "fair value" pricing; finally, measuring the scale of arbitrage trades within the fund. However, the effectiveness of this mechanism is unclear. Individual investors may lack the combination of knowledge and information to monitor funds, or the monitoring cost is too high relative to the benefit. Hence adherence to best mutual fund governance is indispensable for both investors' protection as well as enhancing effectiveness of the fund itself.

In this backdrop, it will be worth to set up the broad objective of the present paper to enquire how far the Indian Mutual Fund Industries fare with respect to protection of stakeholders value protection in general and shareholders' value creation in particular in light of recommendations made by some nationally and internationally acclaimed codes/laws of promoting good governance in mutual fund sector.

Since, for Mutual Fund Companies operating in India there are no specific codes of corporate governance is applicable like corporate governance codes applicable for listed banking companies operating in India, hence the analysis will only be concentrated on Indian Banking companies. However, for having an overview on state of affairs of Mutual Fund Companies corporate governance structure, an attempt will be made to enquire into composition of board of directors' structure of Asset Management Companies (AMC) of Mutual Fund Companies operating in India.

\section{Data Source \& Methodology}

Data were collected mainly from the secondary sources. The secondary data for this present study was based on annual reports of the mutual fund companies, research publications, books, journals, reports in newspapers, electronic newsletters of different professional institutions as well as corporate houses, websites of 
the asset management companies of these mutual fund companies, publication of corporation rankings by different Indian as well as different international agencies were also consulted as and when required. The board of directors' structure of the asset management companies of 21 leading mutual fund companies as on 2006-07 had been considered for the purpose of the study. The board of directors of these companies had been classified into three major categories-independent directors (ID), non-executive directors (NED) and executive or wholetime directors (ED). Since, as per the solution to the agency theory problem, a lot of trust had been imposed to the external independent directors for keeping the spirit of corporate governance high, hence it will be observed especially for the AMCs of these surveyed mutual fund companies operating in India.

\section{Literature Survey:-}

A few studies had been undertaken both home and abroad on mutual fund governance effectiveness. However, a brief review of sum of the significant studies made on enquiring corporate governance system in Banking and Mutual Fund Sector is enumerated here.

Fama and Jensen (1983)'s argued that investors' ability to withdraw money from fund is an effective governance mechanism. Fama and Jensen (1983) also argued that boards of mutual funds are irrelevant because of investors' monitoring. It implies a substitution effect between the external and internal monitoring: boards should be more effective when market monitoring is weak.

The existing studies of fund governance focus on the board of directors' and concluded that boards of smaller size and higher independence are effective monitors. They negotiate lower fees for shareholders (Tufano and Sevick 1997) and are more likely approve open-ending decision of closed-end funds (Dann, Del Guercio and Partch 2002).

Herman (1981), Whisler (1984) and Mace (1986) showed that management effectively chooses the board. Hence, individual board members are reluctant to step forward to oppose management when disagreements arise.

Some studies suggest that collusion exists between the board and management. Tufano and Sevick (1997) find that well-paid independent directors approve higher fees for fund sponsors. The endogeneity problem6 of board composition is reduced in this paper when the board and management are controlled for in one setting.

Uzun, Szewczyk, and Varma (2004) find that larger size, lower independence, and higher grayness of the board are associated with a higher likelihood of corporate fraud.

Christofferson, Evans, and Musto (2005) showed that investors are less likely to withdraw money from underperforming funds, if the shares are purchased through an in-house brokerage. Jay WellMan \& Jian Zhou(2005) for the first time studied the relationship between mutual fund governance and mutual fund performance. Using the first release of the Morningstar Stewardship Grades on August 24, 2004, they found that funds receiving good grades outperformed funds with bad grades by 23 basis points per month over 1/2001 $7 / 2004$ and by 18 basis points per month over 9/2004-12/2004. Of the five variables Morningstar uses to compute their grades, the Board Quality variable showed the most explanatory power. In an examination of daily fund flows subsequent to the announcement date, they observe some evidence that investors sold funds with poor grades and bought funds with good grades.

Ding \& Wermers (2005) have found that when funds have larger boards and higher proportion of outside directors, there is larger possibility of replacement of poor performing managers.

Syed Nadeem \& Saeed M. Akbar (2005) had studied the corporate governance mechanism in Pakistan and observed that institutional owners have grown enormously and have become key players in equity markets. Since they own shares in companies on behalf of a large number of investors, they can and should play an active role in monitoring performance of investor companies.

A Study made by Qian (2006) examined the effectiveness of this market monitoring mechanism in relation to the trading scandals erupted in 2003. With a sample of 92 fund families and 10220 funds classes find that the probability of being indicted is higher for younger funds, funds whose boards are excessively paid, and funds whose money flow is insensitive to past returns. In funds with higher flow sensitivity, there are less stale pricing and less abnormal flows, implying less opportunistic trading. These findings suggest that investors' ability to withdraw from or add assets to funds is an effective fund governance mechanism. This paper introduces various new variables of board structure, composition, and compensation to measure the board's effectiveness in monitoring, and fund and management characteristics to capture managerial incentives. These variables are controlled for in the analysis and the paper finds that the size of the fund has a convex relation with the likelihood of the indictment. A unitary board structure, where one board oversees all funds in the family, is negatively associated with the likelihood of the fund being indicted. Board members in the indicted funds are excessively compensated compared to those in the funds not indicted. Board composition has limited explanatory power for trading violations. In addition, there is some but weak evidence on the substitution effect between internal and external monitoring. That is, in funds with weak market monitoring measured by low flow 
sensitivity, the board of directors makes important differences in influencing fund behaviors. It also observed that funds with higher flow sensitivity to returns are less likely to be involved in trading violations. Good reputation is also an effective governance mechanism. Funds with longer histories are less likely to be involved in the illegal maneuvers. This study gives mixed evidence of whether an effective board requires a higher independence ratio or an independent chairman, but does suggest the importance of market monitoring and the incentive of the board of directors.

Paul Dunn (2009) had studied the disclosure transparency of socially responsible mutual funds. By using a sample of 45 Canadian mutual fund managers that manage 1,650 individual funds, this study found that disclosure transparency increased when mutual fund managers have a greater commitment to providing socially responsible mutual funds.

\section{Governance in Mutual Fund Industries}

Although the codes of corporate governance for mutual fund industries in home and abroad are a few as compared to their counterpart applicable for joint sector companies, yet an initiative was undertaken by US capital market regulator Securities and Exchange Commission through proposing best codes of corporate governance for mutual fund companies. Salient features of such code are as follows-

i. Independent Composition of the Board.

Independent directors would be required to constitute at least 75 percent of the fund's board.

ii. Independent Chairman

The board would be required to appoint a chairman who is an independent director.

iii. Annual Self-Assessment

The board would be required to assess its own effectiveness at least once a year.

iv. $\quad$ Separate Meetings of Independent Directors

The independent directors would be required to meet in separate sessions at least once a quarter.

\section{v. Independent Director Staff}

The fund would be required to authorize the independent directors to hire their own staff.

vi. Codes of Ethics for Investment Advisers.

The fund should have a distinguished and well-orchestrated set of codes of Ethics for Investment Adviser.

The Association of Mutual Funds in India (AMFI) had also prescribed a code of ethics for the professional portfolio managers in India for protecting the investors' interest by defining and maintaining high ethical and professional standards in the mutual fund industry. It had constituted a committee under the chairmanship of Shri A. P. Pradhan to promulgate the code of ethics for implementation by its members.

a) Integrity:-Members and their key personnel, in the conduct of their business shall observe high standards of integrity and fairness in all dealings with investors, issuers, market intermediaries, other members and regulatory and other government authorities. Mutual Fund Schemes shall be organized, operated, managed and their portfolios of securities selected, in the interest of all classes of unit holders.

b) Due Diligence:- Members shall have and employ effectively adequate resources and procedures which are needed for the conduct of Asset Management activities.

c) Disclosures:-Members shall ensure timely dissemination to all unit holders of adequate, accurate, and explicit information presented in a simple language about the investment objectives, investment policies, financial position and general affairs of the scheme.

d) Transparency:- All transactions of purchase and sale of securities by key personnel who are directly involved in investment operations shall be disclosed to the compliance officer of the member at least on half yearly basis and subsequently reported to the Board of Trustees if found having conflict of interest with the transactions of the fund.

e) Professional Selling Practices:-Members shall not use any unethical means to sell, market or induce any investor to buy their products and schemes.

\section{Findings of Studies on Mutual Fund Governance:}

An empirical study was undertaken to study board structure of twenty one mutual fund companies in India for the period 2006-07. The board of directors of such mutual fund industries are mainly analyzed under two categories- Executive directorship and Non-executive directorship. The findings of the study is shown below- 


\begin{tabular}{|l|c|c|c|}
\hline \multicolumn{1}{|c|}{ Name of M.F. } & BoD & NED & ED \\
\hline Benchmark & 5 & 3 & 2 \\
\hline Birla & 8 & 3 & 5 \\
\hline Chola & 11 & 2 & 9 \\
\hline Bob Pioneer & 10 & 5 & 5 \\
\hline UTI & 6 & 5 & 1 \\
\hline ING & 8 & 6 & 2 \\
\hline KOTAK & 6 & 4 & 2 \\
\hline Canara Robeco & 8 & 4 & 4 \\
\hline Franklin & 3 & 2 & 1 \\
\hline HDFC & 12 & 6 & 6 \\
\hline HSBC & 6 & 5 & 1 \\
\hline ICICI-Pru & 11 & 7 & 4 \\
\hline JM & 8 & 4 & 4 \\
\hline Kotak & 6 & 3 & 3 \\
\hline LIC mf & 7 & 3 & 4 \\
\hline Principal & 6 & 3 & 3 \\
\hline Reliance & 4 & 3 & 1 \\
\hline Sahara & 5 & 2 & 3 \\
\hline Sundaram BNP & 7 & 5 & 2 \\
\hline TATA & 6 & 5 & 5 \\
\hline Taurus & 6 & 5 & \\
\hline
\end{tabular}

\section{Chart- Board of Directors Structure of Asset Management Companies of M.F. Companies}

(i) It appears from the above analysis of the asset management companies structure of the above 21 Mutual Fund Companies operating in India that all the companies board have been boosted by the presence of Independent directors. Even the companies like Benchmark, UTI, ING, Kotak, Franklin Templeton India, HSBC, ICICI-Prudential, Reliance Mutual, BNP-Paribas Mutual Fund and Tata Mutual Fund have more than 1/2 of the board of AMC constituted by Independent Directors, while the list is dominated by HSBC Mutual Fund and UTI Mutual Fund. However, the board of directors of asset management companies (AMC) of mutual funds like Bank of Baroda -Pioneer, Canara-Robeco, HDFC Mutual Fund,JM, Principal and Kotak Mutual Fund had exactly $50 \%$ of the board consisted by Independent Directors. But, the BoDs structure of AMC Fund companies like CholaMandlam Mutual Fund and Taurus Mutual Fund are not encouraging enough where both of them hovers below $30 \%$ mark.

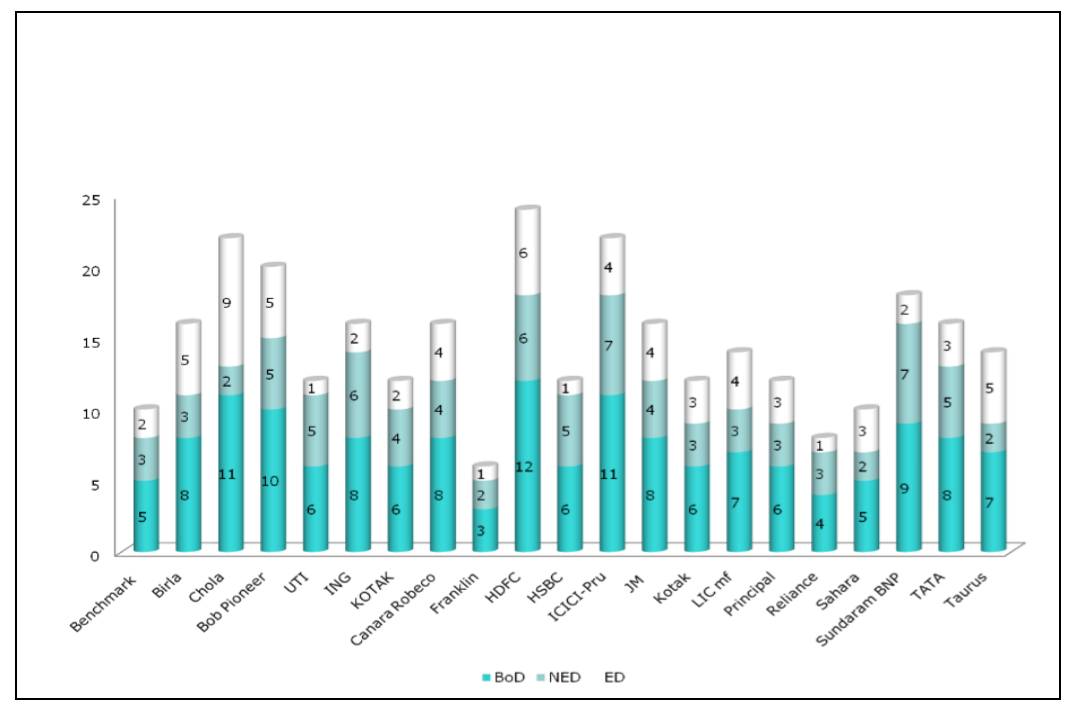

Figure1: Board of Directors Structure of AMCs of MF Companies in India.

(ii) There is no uniformity in the size of board of directors. The number of directors in the board varies from 3 to 12 with the average size of the board being 7.33. Information regarding board size is given in the following Figure-2. 


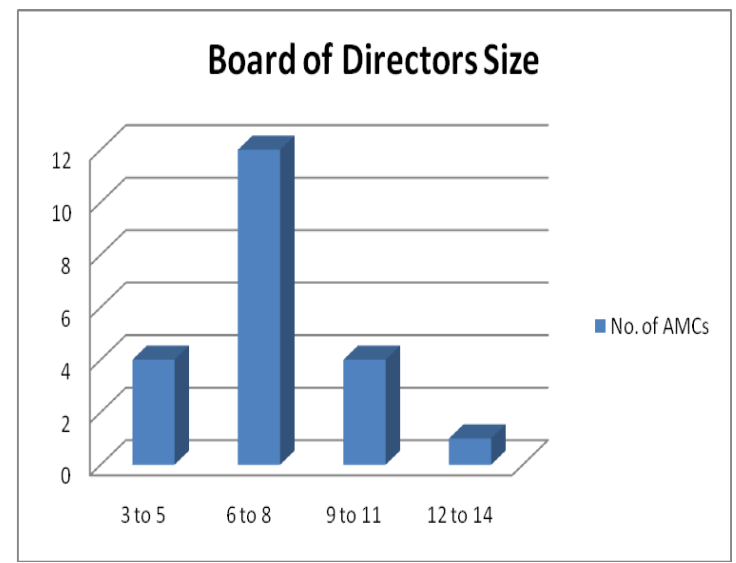

Figure-2: Distribution of Board of Directors in AMCs of MF companies.

It can be observed that from the above figure that the maximum numbers of AMCs (12) are in the $2^{\text {nd }}$ interval i.e. 6-8 directors, in just previous and succeeding class to that particular group there are equal preferences in terms of number of companies i.e. 4.

(iii) From the study, it was revealed that most of the companies showed preferences towards appointment of retired bureaucrats and professionals in the board as independent directors. The average age of independent directors is well above 60 years. For some companies, the average age of independent directors exceeds more than 70 years.

(iv) In India, since there is no legal mandatory provision to appoint an independent director as the chairman of the board, hence this significant provision, regarded as one of the key parameter for good governance, had not been disclosed by almost all AMCs of the MF companies operating in India.

(v) The AMCs had not disclosed any information about the formation of different board committees like audit committee, remuneration committee, corporate governance committee, nomination committee, investor grievance committee, which are considered to be significant measure to keep high the spirit of good governance in an organization.

(vi) The significant apex body of any mutual fund company is its Trustee, created by its primary sponsor, who had the primary responsibility to appoint the Asset Management Company (AMC). However, from the study, it was revealed that all most all the Mutual Fund companies had trustees registered as private limited companies. This choice had made these trustees to be exposed on lesser legal formalities and disclosures.

(vii) All the AMCs have appointed at least one, sometimes more than one custodian for all their schemes. The custodians are generally clustered with foreign banks like Standard Chartered Bank, JP Morgan, Citi Bank, Deutsche Bank, HSBC, Bank of Nova Scotia and Indian entities like HDFC and Stock Holding Corporation.

(viii) As per the legal provisions AMCs are performing the activities of transfer of units either in-house or through a SEBI registered registrar. It was revealed from the study that AMCs had a strong preference for two entities like Computer Age Assets Management Limited (CAMS) and Karvy.

(ix) The auditors of the mutual fund schemes is generally concentrated with a few most reputed auditing firms like PricewaterhouseCoopers India (PWC), S R Batliboi, Haribhakti, NM Ranji, BSR etc.

$(\mathrm{x})$

\section{Policy Implications and Conclusions:}

As far as corporate governance movements in India are concerned, the governance in mutual fund sector is the most low profile sector. But in terms of growth of this sector and the magnitude of public funds they are transacting every day, a complete change in the view should be high on the agenda of regulators like SEBI, DCA and organizations like AMFI. Here a list of some important suggestions can be made-

(a) The market regulators like SEBI, DCA should come up with a separate code/law of good corporate governance for AMCs of mutual fund companies operating in India like clause 49 of the listing companies. That particular code/law should address industry specific issues and should be directed for protection of the interests of common unit holders,

(b) SEBI and/or DCA should specify the minimum number of directors in the board of AMCs with mandatory provisions of including at least half of the board should be constituted by the independent directors. For that purpose, the act should specify the conditions to be fulfilled by an individual for appointment as an 'independent' director. 
(c) DCA or SEBI may also consider the provision of nominating a director in the trustee or board of trustee as an independent director. The details about the functioning, frequency of meetings of trustees, related party information should be disclosed by the mutual funds on annual basis.

(d) The AMCs should have board committees like audit committee, remuneration committee, corporate governance committee, nomination committee, investor grievance committee etc. for ensuring that good governance prevail in the companies.

(e) The concept of 'whistle blowing' had become popular soon after the fall out of Enron, Worldcom and also regarded as a good measure for keeping high the spirit of good corporate governance. The application of that particular mechanism in governance of mutual fund sector may also be considered seriously.

(f) The most alarming state in governance mechanism of mutual fund companies in India is that there are considerably low amount of disclosure regarding functioning of the management of these companies. Regulatory body like SEBI or Department of Company Affairs (DCA) should make it mandatory for the AMCs of the mutual fund companies operating in India to disclose annually their corporate governance aspects along with certification by the auditors. The corporate governance report should contain the information like board of directors' structure, composition, appointment/ re-appointment procedure of directors, formation of different board committees, the functioning of board and committees, frequency of meeting of board and board committees etc.

(g) SEBI and/or DCA may make it mandatory to appoint an independent director as the chairman of the board and may also consider the issue like separation of chairman and executive director.

(h) Since the a few auditors are being appointed as an external auditor of various schemes of mutual fund companies in India, the regulatory body may consider the provision of restriction of appointment of auditor in schemes of the company and/or may consider the provision of compulsory rotation of auditors for every four years.

\section{References}

[1] Adams, R and Mehran, H. (2003). Is corporate governance different for bank holding companies. Economic Policy Review, April, pp.123-41.

[2] Bhargava, B., Dubofsky, D. (1998). Exploiting international stock market correlations with open end international mutual funds. Journal of Business Finance and Accounting, 25, pp.765-773.

[3] Chalmers, J., Edelen, R. and Kadlec, G. (2001). On the perils of financial intermediaries setting security prices: the mutual fund wild card option. The Journal of Finance, 76(6), pp.2209-2236.

[4] Del Guercio, D. and Tkac, P. (2002). The determinants of the flow of funds of managed portfolios: mutual funds versus pension funds. Journal of Financial and Quantitative Analysis, 37, pp.523- 557.

[5] Del Guercio, D., Dann, L. and Partch, M. (2003). Governance and boards of directors in closed-end investment companies. Journal of Financial Economics, 69, pp.111-152.

[6] Edelen, R. (1999). Investor flows and the assessed performance of open-end mutual funds. Journal of Financial Economics, 53, pp.439-466.

[7] theory of the firm. Journal of Political Economy, 88, pp.288-307.

[8] Fama, E. and Jensen, M. (1983). Separation of ownership and control. Journal of Law and Economics, XXVI, June.

[9] Fich, E. and Shivdasani, A. (2006). Are busy boards effective monitors?. Journal of Finance 61(2),pp.689-724.

[10] Greene, J. and Hodges, C. (2002). The dilution impact of daily fund flows on open-end mutual funds. The Journal of Financial Economics, 65, pp.131-158.

[11] Klein, A. (1998). Firm performance and board committee structure. Journal of Law and Economics, 41, pp.257-299.

[12] Hermalin, B. and Weisbach, M. (2003). Boards of directors as an endogenously determined institution: a survey of the economic literature. FRBNY Economic Policy Review,April, pp.7-26.

[13] Investment Company Institute. (2003). Mutual fund independent directors: A model of corporate America?. Fundamentals Vol.9, No.4.

[14] Johnson, W.(2005). Who monitors the mutual fund managers, new or old shareholders. Unpublished working paper. University of Oregon.

[15] Levitt, A. and Dwyer, P. (2002). Take on the Street: What Wall Street and Corporate America Don't Want You to Know, What You Can Do to Fight Back. Pantheon Books, New York.

[16] Mckinsey \& Company. (2002), Global Investor Opinion Survey

[17] Nadeem, A.S. and Akbar, S.M. (2005). Corporate governance of mutual funds in pakistan. accessed from http://ravi.lums.edu.pk/cmer/Conference2005, last accessed on $17^{\text {th }}$ January, 2011.

[18] Pozen, R. (1998). The Mutual Fund Business. The MIT Press, Cambridge.

[19] Scholes, M. and Williams, J. (1977). Estimating betas from nonsynchronous Data. Journal of Financial Economics, 5, pp.307-327.

[20] Sirri, E. and Tufano, P. (1998). Costly search and mutual fund flows. Journal of Finance, 53, pp.1589- 1622.

[21] Tufano, P. and Sevick, M.(1997). Board structure and fee-setting in the US mutual fund industry. Journal of Financial Economics, 46, pp.321-335.

[22] Wellman, J.W. and Zhou, J. (2007). Corporate governance and mutual fund performance: a first look at the morningstar stewardship grades. accessed from SSRN: http://ssrn.com/abstract=714303, last accessed on $18^{\text {th }}$ February, 2011.

[23] Uzun, H., Szewczyk, S. and Varma, R. (2004). Board composition and corporate Fraud. AIMR, May/June, pp.33-43.

[24] Varma, R. (2003). An empirical examination of sponsor influence over the board of directors. The Financial Review, 38, pp.55-76.

[25] Zitzewitz, E. (2003a). Who cares about shareholders? arbitrage-proofing mutual funds. Journal of Law, Economics and Organizations, 19, pp.225-266. 